\title{
Christian Advocacy Ministry on Pandemics: The Ghanaian example on HIVIAIDS
}

\author{
Kwabena Opuni-Frimpong ${ }^{1}$ \\ ${ }^{1}$ Department of Religious Studies - Kwame Nkrumah University of Science and Technology, Kumasi - Ghana.
}

\begin{abstract}
The study is an examination of the various Christian advocacy approaches that the church in Ghana has adopted in its role in the fight against the AIDS pandemic. The study seeks to make the Ghanaian experience available for Christian advocacy ministry for other pandemics. The study as a qualitative one focused on library research. Available primary and secondary materials on the church's participation in the AIDS pandemic were examined and analyzed. Much attention was paid to reports, addresses, study materials and policy documents on the pandemic by the World Council of Churches, Christian Council of Ghana and the Presbyterian Church of Ghana. The study has observed that provision of leadership, capacity building of church leaders, education and awareness creation, the relevance of the Christian message of hope in a moment of despair and Christian advocacy ministry have made significant contributions to the Christian advocacy on the HIV/AIDS in Ghana. The study further provides insights for studies in church and society and the construction of public theology on pandemics in African Christianity.
\end{abstract}

\section{KEYWORDS}

Advocacy Ministry, Pandemics, Capacity Building, Church Leadership

Correspondence:

Kwabena Opuni-Frimpong

Email: opuni@hotmail.com

Publication History

Received 29th September 2021, Accepted 26th October 2021,

Published online 3rd November 2021.

\section{INTRODUCTION}

The World Council of Churches (WCC) invited the global Christian community to mount Christian advocacy ministry on the Human Immunodeficiency Virus (HIV) and Acquired Immunodeficiency Syndrome (AIDS) pandemic due to its massive negative impacts both on the society and the church. The executive committee of the World Council of Churches in 1987 called the church to address the urgent challenges posed by the spread of HIV/AIDs throughout the world. The WCC appealed for an 'immediate and effective response in the areas of pastoral care, education for prevention and social ministry.'

The HIV/AIDS pandemic raises difficult theological questions in the areas of creation, human nature, the nature of sin and death, the Christian hope for eternal life and the role of the body of Christ. ${ }^{2}$ The church's response to the challenge of HIV/AIDS therefore was considered to come from the deepest theological convictions about the nature of creation, the unshakable fidelity of God's love, the nature of the body of Christ and the nature of the Christian hope. ${ }^{3}$ The WCC noted in its appeal that, 'the AIDS crisis challenges us

\footnotetext{
Facing AIDS, the Challenge, the Churches'Response: A World Council of Churches Study Document. Geneva: WCC Publications, 2001.

2 Facing AIDS, the Challenge, the Churches'Response: A World Council of Churches Study Document.

3 Facing AIDS, the Challenge, the Churches'Response: A World Council of Churches Study Document.
} 
profoundly to be the church in deed and in truth: to be the church as a healing community.' ${ }^{4}$

The individual churches and ecumenical bodies in Ghana responded to the call to participate in Christian advocacy on the pandemic. The greatest challenge for the church was how to keep HIV/AIDS on the agenda of the church. Sam Prempeh admitted that, "the church is strategically placed to facilitate, help, conscientize and put a dynamic response to the HIV/AIDS pandemic because the challenge the pandemic poses affects the church as well. ${ }^{\prime 5}$ It became clear when the church accepted to be part of the fight against the pandemic that the church would need a plan for its advocacy ministry. Prempeh further noted that, "what is lacking is a strategic battle plan to impact on the prevention, education, care and support of the disease.' 6

The church subsequently evolved varied programmes, policies, and practices to facilitate its Christian advocacy ministry on the pandemic. One of the strategies of the Christian Council of Ghana for example is to "promote the co-operation of religious groups and provide an inter-faith forum for joint action on issues affecting the larger society. The inter-faith approach is thus a tool to bring about sustainable peace and promote peaceful co-existence among people of different faiths and to expand the coverage area of the response. ${ }^{7}$

In order that the Presbyterian Church of Ghana could define clearly the role it would play now and in the near future in this ongoing exercise, it found it necessary to formulate and develop a Pastoral Policy that is informed by Biblical principles. ${ }^{8}$ In the light of this understanding, the Church has evolved a comprehensive policy that will commit its members to 'a ministry of Christian hope, reconciliation and healing within the congregations and communities.'

The study is an evaluation of the Christian advocacy responses by the church in Ghana towards the HIV/AIDS pandemic and how the pastoral policies, principles, practices, and programmes adopted provide patterns for Christian advocacy ministry on other pandemics. The study it is expected will make further contributions to studies on and construction of public theology in African Christianity as indicated by Kare ${ }^{10}$ and Kim. ${ }^{11}$

\section{METHODOLOGY}

The study as being a qualitative one, focused on library research. Available primary and secondary materials on the church's participation in the AIDS pandemic were examined. Much attention was paid to reports, addresses, study materials and policy documents on the pandemic by the World Council of Churches, Christian Council of Ghana and the Presbyterian Church of Ghana.

\section{The Church and the Aids Pandemic in Ghana}

The HIV/AIDS pandemic has had a socio-economic impact on Ghana. The challenge of the pandemic has equally affected the church and church leaders as well. Pastors have been called upon to provide pastoral care and counselling to church members who have received positive test results of HIV/AIDS and are suffering from shock and stigmatization. Some Pastors have paid visits to church members infected with the virus and have been called to bury church members who have died out of HIV/AIDS. Churches have provided financial support to orphans whose parents have died as a result of the pandemic. Churches have come to the realization that the AIDS challenge is the church's challenge. The challenge is to live out the compassion of Christ and meet the needs of the people who are infected and affected by the pandemic. ${ }^{12}$

In the early years of the HIV/AIDS pandemic, some people thought that it was someone else's problem, if it was a problem at all. Certainly, some church leaders and members did not think that they needed to struggle with the problem. They thought that HIV/AIDS was God's punishment upon sinners. AIDS for

\footnotetext{
4 Facing AIDS, the Challenge, the Churches' Response: A World Council of Churches Study Document.

Presbyterian Church of Ghana. Pastoral Policy on HIV/AIDS, February 2002.

6 Presbyterian Church of Ghana. Pastoral Policy on HIV/AIDS.

7 James Anquandah, Agenda Extraordinaire: 80 years of the Christian Council of Ghana 1929-2009, (Accra: Asempa Publishers 2009), 76.

8 Presbyterian Church of Ghana. Pastoral Policy on HIV/AIDS.

9 Sam Prempeh, Presbyterian Church of Ghana. Pastoral Policy on HIV/AIDS February 2002.

${ }_{10}$ August T. Karel The Quest for Being Public Church, The South African Challenge to the Moravian Church in Context 17372004. Bellville: The Print-Man 2009.

11 Sebastian Kim, Theology in the Public Sphere: Public Theology as a Catalyst for Open Debate. (London: SCM Press 2011).

12 John Stott. Issues Facing Christianity Today. (London: Marshall Pickering 2006).
} 
example was considered in acronym as 'Almighty Is Destroying Sinners' by some Pastors at an HIV/AIDS workshop. ${ }^{13}$ The perception later changed as most people in Ghana later became aware that HIV/AIDS is a disease and not a divine judgement nor is it a curse by witchcraft. AIDS is real and not a respecter of persons as both believers and non-believers, young and old have become infected and affected.

Churches at a point accepted to do something about the disease which had assumed a pandemic dimension, and the threats that it poses. The threats of the HIV/AIDS are not people, although people introduce the threats. The real threats are lust, pride and other forms of selfishness. Ignorance and indifference have been considered as factors that sustain the threats and give a strong place to cause harm in the communities and in churches. ${ }^{14}$

Some churches accepted the understanding of the fact that the church is strategically placed to facilitate, help, concretize and put a dynamic response to the HIV/AIDS pandemic as the challenge of the pandemic had become the church's challenges too. It became clear when the church accepted to be part of the fight against the pandemic that it would need a plan for its advocacy. Olav Fykse Tveit has opined that in the effort to bring faith perspectives on public issues the church must always be guided by scripture and theology. ${ }^{15}$ According to Prempeh, 'the church is strategically placed to facilitate, help, concertize and put a dynamic response to the HIV/AIDS pandemic, what is lacking is a strategic battle plan to impact on the prevention, education, care and support of the disease. ${ }^{16}$ HIV/AIDS is a new disease to the communities, and it has as of now no known cure. The response of the church definitely has to be sincere to scripture and Christian theology as it also seeks to be relevant in the face of a global pandemic.

The AIDS challenge requires both individual appeal and persuasion as well as social involvement. The big challenge for the church is how to keep HIV/AIDS on the agenda of the church. HIV/AIDS is no more looked at only as a health issue. It is a developmental issue that impacts all segments/sectors of society. An enabling involvement needs to be created to reduce the vulnerability of young people to HIV/AIDS. What is important in attacking the epidemic is not just what is done but equally important is how it is done. It, therefore, became clear that there should be openness about the pandemic in order to dissipate fear and prejudice. If the problem is hidden it would then appear that no problem exists. ${ }^{17}$

\section{Young People and the AIDS Pandemic}

The Ghana AIDS Commission has revealed the vulnerability of young people to the AIDS pandemic. Out of the 18,928 new HIV/AIDS infections in 2020, a total of 5,211 are young people between the ages of 15 and 24 , representing $28 \%$ of all new infections in $2020 .{ }^{18}$ The vulnerability of the young people to the AIDS pandemic according to Kyeremeh Atuahene the Director General of the Ghana AIDS Commission is due to 'disregard for education on HIV/AIDS. ' ${ }^{19}$ In explaining the factors behind the vulnerability of the young people to the pandemic, Kyeremeh Atuahene noted that, 'while some of the older men and women take advantage of the vulnerability of the young people, many of the young people voluntarily have sex with older men and women for financial gains. ${ }^{20}$

The church must however, be aware of the positive impact which young people can make on prevention and support efforts. Young people can protect their own lives if they are well informed and have the skills and opportunity to protect themselves. Young people can change the world if they are well equipped. Informed and empowered young people can reduce their risk of contracting HIV. It was noted that, 'information alone would not be enough for the young people. They would need the right to skills, services, supportive environment and

\footnotetext{
13 Presbyterian Church of Ghana. Report on HIV/AIDS/std Education Programme for the Youth 2002.

14 Kwaku Yeboah, Address presented as the Programme Manager, National AIDS Control Programme on the occasion of HIV/ AIDS programme Launch by the Presbyterian Church of Ghana at the Covenant Congregation Dzorwulu on Friday February 23, 2001.

15 Olav Fykse Tveit. The Role of Religion in Sustainable Development and Peace. Berlin World Council of Churches. February 17-18, 2016.

16 Presbyterian Church of Ghana. Pastoral Policy on HIV/AIDS February 2002.

17 Yeboah, Address presented as the Programme Manager, National AIDS Control Programme

18 Atuahene Kyeremeh,. 2020 Report of the Director General of Ghana AIDS Commission.

19 Kyeremeh. 2020 Report of the Director General of Ghana AIDS Commission.

${ }^{20}$ Kyeremeh. 2020 Report of the Director General of Ghana AIDS Commission.
} 
opportunity to participate in the fight against the pandemic. ${ }^{21}$

There is therefore the need for young people to be taught the skills to abstain from sex until they are mature and responsible enough. When they are mature and ready for sex, they should also learn skills for negotiating for safer sex. There was the need to lay a lot of emphasis on the utilization of values, attitudes and life skills approaches. The attitude of church leaders was considered to be essential to support young people to stay away from HIV/AIDS rather than deny and discriminate against them. ${ }^{22}$

An enabling involvement needs to be created to reduce the vulnerability of young people to HIV/ AIDS. What is important in attacking the pandemic is not just what is done but equally important is how it is done. Yeboah opined that, "there should be openness about the pandemic in order to dissipate fear and prejudice. If the problem was hidden it would then appear that no problem exists. ${ }^{23}$

Multiple and complementary strategies must be used in reaching out to young people. Programmes targeting young people must be focused in terms of themes and or geographical location since it would be impossible to reach everyone at the same time. All stakeholders are expected to have a long-term view in mind and at no stage should any party demonstrate complacency. ${ }^{24}$

In talking to young people about HIV/AIDS, it was perceived that they have to be involved themselves because they are agents of change. Young people should be involved as advisors and decision makers. The language used should be acceptable to them in order to be able to use positive messages as much as possible to focus on positive attitudes and actions. Focusing solely on the dangers of HIV alienates young people from taking responsibility in the face of HIV/AIDS.

It is expected that messages for the young people on the pandemic should be tailored to reflect the specific regional and cultural practices for the targeted age groups. The messages should also reflect the teachings of the Bible. Fear should not be implied in the messages. Moralizing and judging turn young people off. Young people were identified as a formidable force in the fight against AIDS because they are part of today's world and would be part of the future. Unless the challenge is accepted to provide an enabling environment to address HIV/AIDS related issues of young people they would not be motivated to do anything for themselves. ${ }^{25}$

\section{The World Council of Churches and the AIDS Pandemic}

The Executive Committee of the World Council of Churches in 1987 called on the church to address the urgent challenges posed by the spread of HIV/AIDS throughout the world. The WCC appealed for an 'immediate and effective response in the areas of pastoral care, education for prevention and social ministry. ${ }^{26}$ The WCC noted in its appeal that, "the AIDS crisis challenges us profoundly to be the church in deed and in truth: to be the church as a healing community. ${ }^{27}$

In 1994 the WCC central committee subsequently commissioned a comprehensive study to be done by a consultative group on AIDS. The study was done on admission that the AIDS impact is on communities and societies all over the world and also that the pandemic had a direct impact on Christians and churches. ${ }^{28}$ HIV is a virus and AIDS is the consequence of viral infection, but the issues raised by the pandemic are far more than purely medical or clinical. They touch on cultural norms and practices, socioeconomic conditions, issues of gender, economic development, human responsibility, sexuality and morality. AIDS has become a development issue. The pandemic adds a heavy burden on the health care system. The cost of treatment is often completely disproportionate to the incomes of the affected families.

The HIV/AIDS pandemic raises difficult theological questions in the areas of creation, human nature, the nature of sin and death, the Christian hope for eternal and the role of the body of Christ. The church's response to the challenge of HIV/AIDS therefore was considered to come from the deepest theological

\footnotetext{
${ }_{21}$ Yeboah, Address presented as the Programme Manager, National AIDS Control Programme.

22 Yeboah, Address presented as the Programme Manager, National AIDS Control Programme.

23 Yeboah, Address presented as the Programme Manager, National AIDS Control Programme.

${ }^{24}$ Yeboah, Address presented as the Programme Manager, National AIDS Control Programme.

${ }_{25}$ Yeboah, Address presented as the Programme Manager, National AIDS Control Programme.

${ }^{26}$ Facing AIDS, the Challenge, the Churches' Response.

27 Facing AIDS, the Challenge, the Churches' Response.

${ }^{28}$ Facing AIDS, the Challenge, the Churches' Response.
} 
convictions about the nature of creation, the unshakable fidelity of God's love, the nature of the body of Christ and the nature of the Christian hope. ${ }^{29}$

The WCC's advocacy on the pandemic is rooted in scripture and theology. God's promise that nothing can separate man from the love of God in Christ was considered to mean that no disasters, no illness or disease, nothing done by man and nothing done to man, not even death itself, can break God's solidarity with all creation. 'Who shall separate us from the love of Christ? shall tribulation, or distress, or persecution, or famine, or nakedness, or peril, or sword? As it is written, for thy sake we are killed all the day long; we are accounted as sheep for the slaughter. Nay, in all these things we are more than conquerors through him that loved us. For I am persuaded, that neither death, nor life, nor angels, nor principalities, nor powers, nor things present, nor things to come, nor height, nor depth, nor any other creature, shall be able to separate us from the love of God, which is in Christ Jesus our Lord (Roms. 8:35-39). The church as the body of Christ is to be the place where God's healing love is experienced and shown forth. As the body of Christ, the church is bound to enter into the suffering of others, to stand with them against all rejection and despair.

The response of the church is to provide a climate of love, acceptance and support for those who are vulnerable to or affected by HIV/AIDS. It is expected that churches would provide better pastoral care for persons affected by the pandemic and pay particular attention to the conditions of infants and children affected by the pandemic and seek ways to build a supportive environment. It is also expected that churches would advocate for increased spending by governments and medical facilities to find solutions to the problems both medical and social raised by the pandemic.

The committee set up by the World Council of Churches on the pandemic subsequently developed policies, programmes and study materials that provided the churches with response to the challenge of facing AIDS. The study material for instance provides information on theological and ethical perspectives, human rights, responsibilities and HIV/AIDS, pastoral care and the healing community to guide the global church in facing HIV/AIDS pandemic.

\section{The Christian Council of Ghana and the AIDS Pandemic}

In 2002, the Christian Council of Ghana collaborated with the Johns Hopkins University Center for communications in organizing programmes that brought together Christian and Muslim clergy and lay leaders and their congregations geared to reducing the incidence of the stigmatization of persons living with HIV/ AIDS, promoting and expanding the campaign of showing compassion for those infected and affected by the disease.

One of the strategies the Christian Council of Ghana uses to promote the co-operation of religious groups is to provide an inter-faith forum for joint action on issues affecting the larger society. The inter-faith approach is thus a tool to bring about sustainable peace and promote peaceful co-existence among people of different faiths and to expand the coverage area of the response. ${ }^{30}$

Inter-faith advocacy workshops were held in 2002 separately for Christian and Muslim leaders for soliciting their active collaboration to support the implementation of church and mosque-based compassion activities to bring hope to HIV/AIDS infected and affected persons. The Christian Council of Ghana further pursued the organization of inter-faith training of trainers' workshops using Johns Hopkins training manual to train persons who in turn would downstream their skills to other trainees in the communities. The Christian Council of Ghana further formed the Joint Working Committee of Christians and Muslim Leaders to promote and coordinate the campaign process. ${ }^{31}$

A major landmark in the operations of the Christian Council of Ghana is the formation of the Local Council of Churches. The major activities of the Local Council of Churches include, worship, study, family life, inter-faith peace and conflict resolution tasks, industrial missions, rural agriculture projects, voter education and election monitoring, refugee camp welfare services HIV/AIDS stigma awareness and rehabilitation campaigns, etc.

In 2004, the Christian Council of Ghana and its Northern Sector Office commenced the HIV/ AIDS programme in six districts of Northern Ghana- West Gonja, Bole, Tolon, Kumbugu, Zabugu/ Tatale,

\footnotetext{
${ }^{29}$ Facing AIDS, the Challenge, the Churches' Response.

30 Anquandah. Agenda Extraordinaire: 80 years of the Christian Council of Ghana 1929-2009, 76.

${ }^{31}$ Christian Council of Ghana General Secretary's Report to the 2004 Annual General Meeting.
} 
Tamale and East Mamprusi. The programme focused on building District HIV/AIDS coalitions involving Local Council of Churches, school clubs, Non-Governmental Organizations, District Health Teams, District Assemblies and Social Welfare Department. The programme sought to reduce prevalent rates, stigmatization and discrimination and promote awareness of the pandemic. ${ }^{32}$

One of the key strategies of the Christian Council on the pandemic has been to target adolescent youth and children. Workshops were organized in 2001-2002 by the Christian Council for the training of peer educators and peer counsellors of the Tesano cluster of schools in Accra to equip them to conduct outreach programmes on HIV/AIDS. School clubs were established at the Tesano cluster of Schools for this purpose. Trainers from these school clubs took it upon themselves to attend youth parties held at the beaches of Accra on Valentine's Day February 14 in order to counsel youths regarding the dangers of HIV/AIDS. ${ }^{33}$

In 2002, the Christian Council hosted over 2000 second-cycle students at Cape Coast and Tema at a series of workshops. The Christian Council initiated a strategy by a package of living testimonies, audio-visuals and printed materials related to HIV/AIDS that was subjected to pre-testing in order to validate them for use by peer educators in their schools and colleges. In December 2006, at their annual inter-youth conference at Tema, the Christian youths, embattled with the HIV/AIDS syndrome, took as their theme 'Youth fight against HIV stigma and Discrimination'.

Another strategic tool initiated jointly by the Christian Council and Johns Hopkins University Center for Communication was the 'Window of Hope'(WOH) campaign. The Window of Hope was an intervention that targeted children in the age bracket of 8-14 years. It sets up workshops to educate them on sexual and reproductive health to equip them adequately to make informed decisions on sex and sex-related issues. During 2001-2006, Window of Hope clubs were formed in selected schools across several areas in Ghana including, Accra, Bortianor, Aflao, Kokrobite, Koforidua, Manhean, Moree, Prampram, etc. ${ }^{34}$

The Christian Council's strategy for adult groups was to raise their interest in developing CommunityBased discussion groups. At a number of workshops held at Aboaso, Kadjebi, Nkwanta and Sokode, adults were furnished with the necessary information to enable them provide leadership in outreach discussion groups to create awareness on HIV/AIDS problems as well as general sexual reproductive health issues.

Another joint Christian Council and Johns Hopkins strategic initiative was the Compassion Campaign. It had been realized from research findings according to the National AIDS Control Programme that one of the reasons for the continued spread of the HIV/AIDS menace was the stigmatization and discrimination that was associated with persons infected and affected by HIV/AIDS. ${ }^{35}$ There was the need, therefore, to mount a campaign of education and the inculcation of the Good Samaritan spirit to eliminate the stigmatization and discrimination connected with the disease.

The Christian Council collaborated with the John Hopkins team and a Forum of Religious Bodies to promote a Compassion Campaign. Workshops were organized in several towns in Southern Ghana especially Accra, Kumasi, Aflao, Prampram, etc. which brought together Christian and Muslim communities. Participants were motivated to show compassion and care for People Living With HIV/AIDS (PLWHA). The beneficiaries of these teachings were required and encouraged to downstream their new learning to their comrades in churches, mosques and families. The trainees were also encouraged and schooled to form Compassion Associations to serve as channels by which home-based care and compassion would be ministered to PLWHA and HIV infected persons.

\section{The Presbyterian Church of Ghana and the AIDS Pandemic}

The Presbyterian Church of Ghana has provided Christian advocacy ministry to the AIDS pandemic. The response is as a result of the church's holistic approach to ministry. ${ }^{36}$ According to Prempeh, 'the Presbyterian Church of Ghana, from its inception as a mission Church, has pursued a holistic ministry with its engagement in evangelism and social services. ${ }^{37}$ The church has over the years provided advocacy ministry to the health

\footnotetext{
32 Christian Council of Ghana General Secretary's Report to the 2004 Annual General Meeting.

33 Christian Council of Ghana General Secretary's Report to the 2004 Annual General Meeting.

34 Christian Council of Ghana General Secretary's Report to the 2004 Annual General Meeting.

35 Yeboah, Address presented as the Programme Manager, National AIDS Control Programme.

36 Emmanuel Asante. Theology and Society in Context: A Theologist's Reflections on Selected Topics. (Accra: Sonlife Press, 2014).

37 Prempeh in Presbyterian Church of Ghana. Pastoral Policy on HIV/AIDS February 2002.
} 
needs of the nation. ${ }^{38}$ In the field of health care delivery, the church has offered numerous services since the 1850s and continues to offer health care. Hospitals, Clinics and Primary Health Care programmes, doted in the rural areas of Ghana, have been dominant areas of operation in the past and continue to engage our attention up till today. ${ }^{39}$

The AIDS pandemic presented challenges to health care providers and churches as it has no cure. The emergence of the HIV/AIDS pandemic with its attendant destruction of many profitable lives has however, opened a whole new chapter in the Church's health care delivery. As part of its holistic ministry, the Church has been fully engaged in mutual partnership with Government, NGO's and other stakeholders to combat the disease in the country. ${ }^{40}$

In order that the Presbyterian Church of Ghana could define clearly the role it would play now and in the near future in this ongoing exercise, it found it necessary to formulate and develop a Pastoral Policy that is informed by Biblical principles. ${ }^{41}$ In the light of this understanding, the Church evolved a comprehensive policy that commits its members to 'a ministry of Christian hope, reconciliation and healing within the congregations and communities. ${ }^{42}$

Prempeh who was the Moderator of the Presbyterian Church of Ghana during the launching of the Pastoral policy on AIDS stated, 'it is therefore my earnest hope and desire that the policy will receive wider readership and that all agents, as well as ordinary members, will do well to study it and faithfully implement the guidelines contained in this policy. I recommend it highly not only for being the baby of Presbyterian Church of Ghana but more than that, I believe, it will form a basis for a continuous process of education, prevention and care of those affected and infected by HIV/AIDS. ${ }^{43}$

\section{Some Lessons for Advocacy on Pandemics}

The church's Christian advocacy on the AIDS pandemic presents lessons that must be considered for similar Christian advocacies on pandemics. The lessons include, provision of leadership, capacity building of church leaders, education and awareness creation, the relevance of the Christian message of hope in a moment of despair and Christian advocacy ministry.

\section{Provision of Leadership}

Leadership was identified as very key in the Christian advocacy ministry on the pandemic by the World Council of Churches, Christian Council of Ghana and the Presbyterian Church of Ghana. They set up committees and made appointments of staff specifically assigned to provide leadership on the advocacy of the pandemic. The AIDS Project of the Presbyterian Church of Ghana, for example, had the Moderator as the chairman of the advocacy ministry on the pandemic.

Specific units and departments were created to coordinate and facilitate the AIDS pandemic advocacy ministry. The AIDS Departments, Unit and committees were tasked to build partnerships and networking with other organizations both local and international who were also into advocacy on the pandemic. The Units were tasked to develop and share information, resources and best practices among the various courts of the church and other similar organizations.

The assigned leadership Units were further made responsible for resource mobilization. The Unit conducted its resources mobilization in matters of funds and technical support. The National AIDS Control Programmes Office of the Ministry of Health provided resource persons with materials who facilitated the training programmes of the Advocacy in churches and training workshops. Donor Agencies like World Health Organization, Family Health International, Johns Hopkins University Center for Communication and USAID that accepted to work with the churches and ecumenical bodies provided the financial needs of the programme. Kwame Essah opined that, "proper engagement can come about if technical experts in HIV and AIDS and religious leaders together develop appropriate programmes and activities for our youth which take

\footnotetext{
${ }^{38}$ Hans W. Debrunner A History of Christianity in Ghana. Accra: Waterville Publishing House 1967.

39 M.A. Kwamena-Poh Vision \& Achievement. (Accra: Waterville Publishing House, 2011).

${ }^{40}$ Presbyterian Church of Ghana. Report on HIV/AIDS/std Education Programme for the Youth 2002.

${ }^{41}$ Presbyterian Church of Ghana. Report on HIV/AIDS/std Education Programme for the Youth 2002.

42 Prempeh in Presbyterian Church of Ghana. Pastoral Policy on HIV/AIDS February 2002.

${ }^{43}$ Prempeh in Presbyterian Church of Ghana. Pastoral Policy on HIV/AIDS February 2002.
} 
into consideration the sensitivities of the religious institutions. ${ }^{44}$

The leadership Units in Ghana collaborated with other ecumenical bodies who were also into the AIDS pandemic advocacy like the All African Conference of Churches and the World Council of Churches. The leadership Units was moreover, tasked to study and evaluate the impact of the programme and make reviews and suggestions for a bigger impact of the programme. The Units prepared and administer questionnaires which were used for the evaluation and reporting of the programme.

\section{Capacity Building of Church Leaders}

The churches' strategic plan for the fight against the AIDS pandemic paid much attention to the capacity building of pastors, youth and students' leaders, ministers' spouses and the Local Council of Churches. They were made aware of the urgency of the response and the churches' role in the fight against the pandemic. The theological and biblical basis was provided to sustain the ministerial confidence of the ministers and they were allowed to encounter and listen to the stories of some church members who have been infected and affected by the pandemic. The ministers considered their role as part of their Christian ministry and missions with confidence..$^{45}$

The impact of the pandemic has been especially on young people and women that are constantly available in the church. The capacity of the church leaders to provide Christian advocacy ministry was very strategic for the church and the Ministry of Health. According to Essah, 'it is evident that religious institutions such as the Presbyterian Church of Ghana when properly engaged can serve as a very powerful medium for breaking the silence on HIV and AIDS. In reality, churches continue to play a very vital role in supporting the sick, the poor, and the handicapped and are very much involved in addressing pressing community concerns. HIV and AIDS are part of the major community concerns. ${ }^{46}$

Family Health International, one of the key partners of the Presbyterian Church, for example, arranged for an International Consultant to assist the church in developing educational materials. Essah remarked, 'our organization has sought the assistance of MAP International, an organization based in Nairobi Kenya and a recognized leader in the development of curricula and models on HIV and AIDS education for Theological and Pastoral training institutions. A representative of MAP International will be here in the first week of April to interact with the leaders of this programme and exchange ideas as to how best HIV and AIDS communication amongst our youth can be implemented such that it would lead to the desired positive behavior change. ${ }^{47}$ The Presbyterian Church of Ghana's advocacy on the pandemic was expected to serve as a model to other churches as indicated by Essah. 'The lessons that will be learnt from these sequences of activities could be shared with other religious bodies that have embarked on the same mission that you have.' ${ }^{48}$

\section{Education and Awareness Creation}

The Christian advocacy of the church towards the pandemic was mainly through education and awareness creation. The people who were infected and affected by the pandemic suffered stigmatization, condemnation and social neglect. Some of the negative reactions to the pandemic came as a result of ignorance, misinformation and half-truths. Proper knowledge and awareness creation were expected to help both church members and Pastors to relate well and provide care and support to those who needed them.

Learning materials were prepared for the church leaders and members for personal and congregation use. The Pastoral Policy gave many insights and was made available to all ministers, ministers spouses, youth leaders and Local Councils of Churches. Audiovisual materials, posters were developed which were made available on church facilities and showed in church. The mode of education included participatory learning, focused group discussion, demonstrations, lectures, videos, role play, drama and case studies. The unique

\footnotetext{
${ }_{44}$ Kwame A.s. Essah, Address Presented As The Resident Advisor Of Family Health International On The Occasion Of Hiv/Aids Programme Launch By The Presbyterian Church Of Ghana At The Covenant Congregation Dzorwulu On Friday February 23, 2001.

45 Sam Prempeh, Address presented as the Moderator of the Presbyterian Church of Ghana on the occasion of HIV/AIDS programme launch by the Presbyterian Church of Ghana at the Covenant Congregation Dzorwulu on Friday February 23, 2001.

46 Essah, Address presented as the Resident Advisor of Family Health International.

47 Essah, Address presented as the Resident Advisor of Family Health International.

48 Essah, Address presented as the Resident Advisor of Family Health International.
} 
approach to reducing stigmatization was the involvement of People Living with AIDS in the programme to share their stories and testimonies.

The Unit was tasked to review existing materials and developed others for training manuals for training, leaflets, stickers, posters, the printing of AIDS Advocacy T-Shirts which were worn with pride at church services and in public. The platforms for awareness included the churches congregations, schools and among students, theological seminaries, pre-marital counselling, ministers, ministers' spouses, prayer camps, generational and other group meetings, conferences, conventions, staff at the various church workplaces, the Local Council of Churches and Christian homes.

\section{Advocacy as Christian Ministry}

The global and national church at a point admitted the impact of the pandemic on the church and society. Church members were infected and affected by HIV/AIDS. The pandemic though was a health issue also became a church and theological issue. The church had to answer the question of 'who is my neighbor' and what help must be given to neighbors who needed urgent help due to the pandemic.

The gift of help and advocacy is mentioned in I Cor 12:28 as part of the gifts of the Holy Spirit. The gift provides the church and its members the special ability to perceive the needs of others, whether physical, emotional, spiritual, etc. and to develop the desire to respond and fulfill those needs, regardless of personal benefit or loss. In the advocacy ministry, the church serves with compassion, humility and grace ${ }^{49}$ Basically, those with the gift of helping will have strong empathy for others and a sense of needs that must be met in individuals' lives. Helpers render their gift of service to build up others, assisting and supporting the body of Christ. Paul admonished the church 'bear one another's burdens, and so fulfil the law of Christ' (Gal 6:2).

The World Council of Churches, the Christian Council of Ghana and the Presbyterian of Ghana have been able to respond to the AIDS pandemic due to their ability to get their members to admit that the pandemic though a health challenge, is also a Christian and theological issue that must attract the Christian response of the church. The challenge is not a secular and social challenge of the nations but it is a spiritual challenge that demands Christian hope, compassion and healing.

\section{CONCLUSION}

The churches and ecumenical bodies in Ghana participated in the fight against the HIV/AIDS pandemic due to its massive negative impacts on society and the church. The initial challenge of placing the pandemic on the agenda of the church led the church to develop pastoral policies, programmes and practices for effective response and impact. The churches' Christian advocacy ministry according to the study has been noted to have paid much attention to the provision of leadership, capacity building of church leaders, education and awareness creation, the relevance of the Christian message of hope in a moment of despair and the need to bring faith perspectives on pandemics. The study has observed that the Ghanaian experience of the church's advocacy on pandemics must be considered in responding to similar pandemics. Moreover, the experience provides resources for the construction of public theology in matters of pandemics.

\section{ABOUT AUTHOR}

Kwabena Opuni-Frimpong ( $\mathrm{PhD}$ ), Lecturer in African Christianity, Department of Religious Studies, Kwame Nkrumah University of Science and Technology, Kumasi - Ghana.

\section{BIBLIOGRAPHY}

Anquandah, James. Agenda Extraordinaire: 80 years of the Christian Council of Ghana 1929-2009. (Accra: Asempa Publishers 2009).

Asante, Emmanuel. Theology and Society in Context: A Theologist's Reflections on Selected Topics. (Accra: Sonlife Press, 2014).

Christian Council of Ghana, General Secretary’s Report to the 2004 Annual General Meeting.

\footnotetext{
49 Kwabena Opuni-Frimpong, Christian Ministry of Advocacy. (Accra: Sonlife Press 2015).
} 
Christian Council of Ghana, General Secretary's Report to the 2006 Annual General Meeting.

Debrunner Hans W. A History of Christianity in Ghana. (Accra: Waterville Publishing House 1967).

Essah, Kwame AS. Address presented as the Resident Advisor of Family Health International on the occasion of HIV/AIDS programme launch by the Presbyterian Church of Ghana at the Covenant Congregation Dzorwulu on Friday February 23, 2001.

Facing AIDS, the Challenge, the Churches' Response: A World Council of Churches Study Document. (Geneva: WCC Publications, 2001).

Karel, T. August. The Quest for Being Public Church, The South African Challenge to the Moravian Church in Context 1737-2004. (Bellville: The Print-Man 2009).

Kim, Sebastian. Theology in the Public Sphere: Public Theology as a Catalyst for Open Debate. (London: SCM Press 2011).

Kwamena-Poh, M. A. Vision \& Achievement. (Accra: Waterville Publishing House, 2011).

Kyeremeh, Atuahene. 2020 Report of the Director General of Ghana AIDS Commission.

Opuni-Frimpong, K. Christian Ministry of Advocacy. (Accra: Sonlife Press 2015).

Prempeh, Sam. Address presented as the Moderator of the Presbyterian Church of Ghana on the occasion of HIV/AIDS programme Launch by the Presbyterian Church of Ghana at the Covenant Congregation Dzorwulu on Friday February 23, 2001.

Presbyterian Church of Ghana. Report on HIV/AIDS/STD Education Programme for the Youth 2002.

Presbyterian Church of Ghana. Pastoral Policy on HIV/AIDS February 2002.

Stott, John. Issues Facing Christianity Today. (London: Marshall Pickering 2006).

Tveit, Olav Fykse. The Role of Religion in Sustainable Development and Peace. Berlin World Council of Churches. February 17-18, 2016.

Yeboah, Kwaku. Address presented as the Programme Manager, National AIDS Control Programme on the occasion of HIV/AIDS programme Launch by the Presbyterian Church of Ghana at the Covenant Congregation Dzorwulu on Friday February 23, 2001. 